\title{
Development of the principles of "Green" logistics in the cities of the Russian federation
}

\author{
Natalia Verstina $^{1} *$, Tatiana Tereshkina ${ }^{2}$ and Marina Treyman $^{2}$ \\ ${ }^{1}$ Moscow State University of Civil Engineering, Yaroslavskoe shosse, 26, Moscow, 129337, Russia \\ ${ }^{2}$ Saint Petersburg State University of Industrial Technologies and Design (SPbSUITD), 191186, 18, \\ Bolshaya Morskaya street, Saint-Petersburg, Russia
}

\begin{abstract}
The matters of the "green" logistics in Russia are considered in the article. The analysis of data on gas emission from motor transport, the influence of transport and logistics system on the environment, and calculation of ecological damage from transport and logistics systems in St. Petersburg are carried out. Methods of the ecology-focused approach to the introduction of the principles of "green" logistics and creation of the ecology-focused logistics systems in the cities are developed.
\end{abstract}

\section{Introduction}

Nowadays the combination of the ecological principles and logistic approaches gains the escalating importance. For the first time the principles of "green" logistics have been considered at the international conference of the UNO, devoted to the matters of sustainable development in Rio de Janeiro in 1992 with the participation of representatives from 179 countries. The conference jointed the results of all the previous conferences, devoted to problems of the environment [14].

The main objective of the concept of sustainable development consists in the development and implementation of methods for the achievement of the balance between the economic, social and ecological sphere of human life; at the same time the overwhelming part the population of the planet lives in the cities and the concentration of the population in the cities constantly increases [14, 21].

The term "green" logistics is a rather wide and multifaced concept, which includes measures for the assessment and lowering of the influence of $\mathrm{CO} 2$ on natural environmental and artificially created environment as the result of logistic activities of the companies, creation of the system of ecologically safe transportation of goods, running vehicles with the use of alternative fuel, change of constructional features of transport for lowering of the negative impact on the environment, routing of logistic flows for the decrease in fuel and operational costs, etc. [10, 31, 33]. Some authors define "green" logistics as the direction in science, allowing to define and reduce environmental risks in logistic activities, taking into account the balance of environmental and economic efficiency in the conditions of the modern city $[7,18,21,26,30]$.

Corresponding author: verstina@mail.ru 
We shall note, that the terminology database of "green logistics" is quite not created and is not systematized, because there are some separate developments and methodologies by the authors, which are not generalized in a single system. This scientific direction develops actively, including the development on the joint with other scientific directions, studying the modern cities development. Scientific and practical activities of "green" logistics are first of all connected with the assessment of the influence of transport on the surrounding environment, which is artificially created by the human (urban development) as its share in the total amount of emissions of harmful substances to the atmosphere from stationary and mobile sources makes up about $70 \%$; that exceeds the share of any other type of economic activity. The condition of vehicles and the means of transport, used for transportation of goods, belong to the transport factors. The existence of well-developed transport network in the built-up territories, optimum structure of the vehicles park (the existence of a certain quantity of specialized transport, vehicles of various loading capacity, etc.), optimum routes of goods delivery in the city, etc. is necessary in order to provide uninterrupted and economically effective functioning of process of merchandising in the modern city.

The anthropogenic influence of transport is expressed in additional emission of pollutants into the atmosphere of the city in places of accumulation of transport, because of backwardness and imperfection of transport network as well as because of the possibility of use of any cheaper types of fuel, which products of processing have negative effect on the state of environment and health of human [5, 13, 15, 16]. The influence of the motor transport on the level of pollution of the urban environment is especially great.

At the same time transport is also the main source of the city noise and it acts as an inevitable, but negative factor during the urban development planning. In case of low motion speeds of transport the source of noise is the noise of engines, and in case of high speeds the source of the noise is the friction between tires and the road carpet. The increase in noise happens because of the increase in average speed of cars, the growth of their density on routes, the increase in the sizes (loading capacity) of vehicles. For example, the quantity of traffic jams influences the amount of consumption of fuel and, respectively, the emission of $\mathrm{CO} 2$. According to the research results, speed below $20 \mathrm{~km} / \mathrm{h}$ gives the significant increase in the emission of $\mathrm{CO} 2$. Besides, it was counted, that if the 40-ton road train does two stops for one kilometre the fuel usage increases approximately three times. It is proved, that the minimum allocation of carbon dioxide gas in the atmosphere happens in case of uniform motion of the vehicle at speed of $40 \mathrm{~km} / \mathrm{h}$ [13].

Utilization of the used automobile tires, accumulators, thrown ownerless old cars and many other dangerous materials, which arise within production, located in the city and behind its line, as well as corrective maintenance of cars is the example of eco-destructive impact of transport on the urban environment. The most typical wastes, such as oils, accumulator acid and antifreeze ( $72 \%$ of the contaminating potential of automobile wastes) belong directly to cars. Distribution of damage from the environmental pollution by different types of waste can be defined as follows: used motor oils $-50 \%$; rechargeable batteries $-15 \%$; antifreeze $-7 \%$; substances for washing and cleaning, paints, glues $-21 \%$; others $-7 \%$ [13].

\section{Materials and Methods}

The negative impact of the logistics system on the environment is considered in scientific literature as the external influences $[11,13]$.

Externalities is the side outer effect of economic activity of the economy subjects, causing damage to the nature and society, and as the conducted research to the environment, which is artificially created by the human (urban development). The nature of externalities is that the harm to the environment is done by the enterprise, which does not 
sustain any essential financial losses, as the ecological damage does not influence internal costs of the enterprise. On the other hand, costs as the result of the caused damage to the nature and society are suffered by the state and population [15].making managerial decisions on providing the sustainable development of the heating systems construction in the built-up territory.

Nowadays there are no techniques for the cost assessment of ecological influence of transport and logistics system on the environment, which is artificially created by the human (urban built-up territory). There is only "Temporary technique of definition of the prevented ecological damage", developed on March 9, 1999, which contains an order and methods of the assessment of the ecological damage, caused by economic systems. This technique assumes accounting of the actual and possible financial losses, suffered by the society and caused by environmental pollution [1].

According to this technique the annual economic damage from receipt to the environment of combustion products of automobile fuel can be determined by the following formula:

$$
E D=\gamma^{*} \sigma^{*} f^{*} M
$$

\section{where}

$\gamma$ - specific damage from the receipt to the environment from the ith component of the exhaust gases (roubles per equivalent ton);

$\sigma$-dimensionless indicator of the relative danger of the exhaust gases to the territory (perception factor indicator);

$f$ - the dimensionless value, which is responsible for the nature of dispersion of impurity in the atmosphere; for gases and aerosols with the low speed of subsidence is accepted, that the coefficient $(f)$ of dispersion of emissions is $f=1$; for emissions of harmful substances from motor transport is $f=10$, for dust and ashes is $f=3$;

$M$ - the specified mass of annual emission of pollutants.

Indexation of specific damage, taking into account inflation, is carried out by the means of $\mathrm{It}^{\mathrm{ind}}$ coefficient.

The value of the specified mass (M) of annual emission of the polluting impurity from the source in the atmosphere is determined according to the formula:

$$
M=\Sigma\left(A_{i} * m_{i}\right) \text {, }
$$

where $m_{i}$ - mass of annual emission of the $\mathrm{i}_{\text {th }}$ type pollutant (tons in a year), $\mathrm{i}=1, \mathrm{~N}$;

$\mathrm{N}$ - total of the impurities in the source emissions;

And - indicator of relative aggression of the pollutant, equivalent ton in a year, for the firm particles which are thrown out by vehicles with diesel engines $A=20.0$ for emissions of nitrogen oxides $\mathrm{A}=41.1$;

For the definition of financial losses of the state budget during compensation of the ecological damage, caused by the motor transport in the conditions of urban development it is expedient to assess damages to health of the population, because the deterioration in health of society is an important component of ecological damage. The technique of this assessment has been offered by S.N. Bobyliov, V.N. Sidorenko [5] according to whom the damage to the population of the modern city is determined by three directions:

- the expenses on treatment of diseases of the population, caused by the adverse environment;

- losses of the Gross Regional Product (GRP) from the population disease;

- losses of the Gross Regional Product (GRP) as the result of the decrease in the life expectancy of the population, caused by the polluted environment. 


\section{Results}

Emissions of pollutants in the atmospheric air from the motor transport in 2017 in Russia (according to official figures of Federal State Statistics Service) made up 14605 thousand tons [12]. In St. Petersburg this indicator was 472.2 thousand tons in 2017. [12]. Dynamics of the emission of harmful gases from the motor transport in St. Petersburg from 2014 to 2017 is presented in the figure 1.

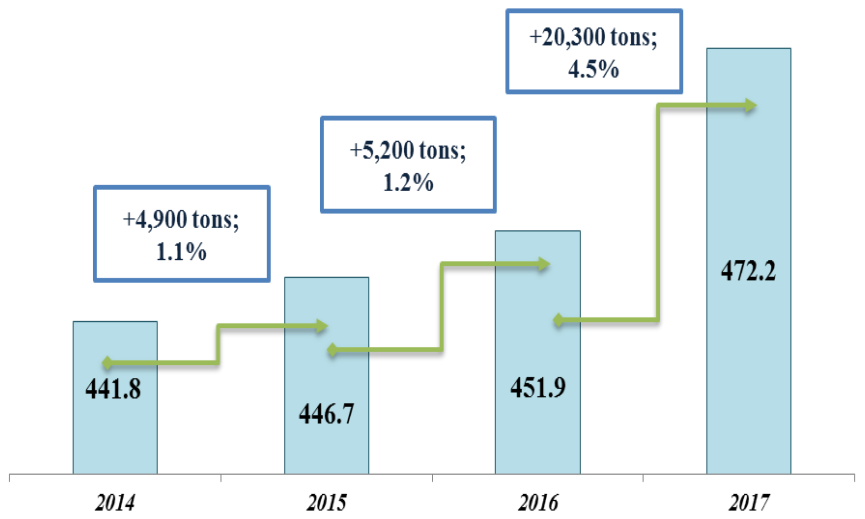

Fig. 1. Dynamics of volumes of gas emissions in St. Petersburg in 2014-2017, thousand tons

For the last year there was the increase in rates of the gain of volumes of emissions; that causes growth of influence of motor transportation emissions on the health of urban population. According to the qualitative structure the basis of emissions in 2017 is made by carbon monoxide, organic substances and nitrogen oxides. The structure of emissions of pollutants from the motor transport for 2017 in St. Petersburg is given in figure 2.

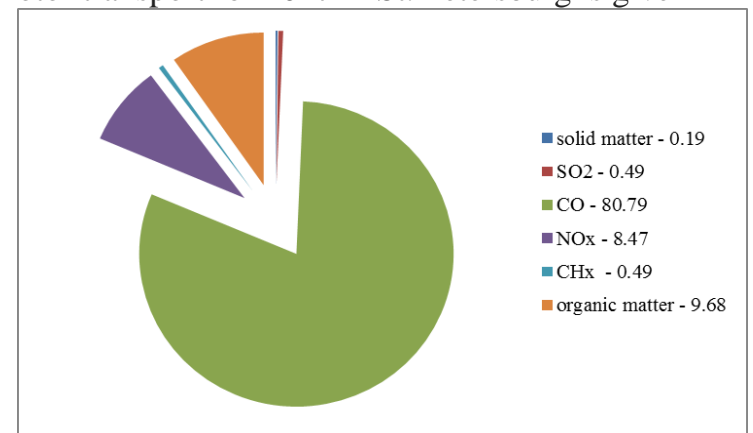

Fig. 2. Qualitative characteristic of pollutants from the motor transport in 2017 in St. Petersburg, \% [6]

The contribution of various types of the motor transport to emissions depending on a type of the used fuel (gasoline, the diesel) in modern conditions in St. Petersburg is presented in Table 1 [6].

Table 1. Share of emissions of pollutants in the atmosphere from the motor transport according to the engine type in St. Petersburg

\begin{tabular}{|l|c|c|}
\hline \multirow{2}{*}{ Vehicle type } & \multicolumn{2}{|c|}{ Fuel type, \% } \\
\cline { 2 - 3 } & Gasoline & Diesel \\
\hline Cars & 50.4 & 0.2 \\
\hline Trucks & 40.5 & 4.0 \\
\hline Buses & 4.7 & 0.2 \\
\hline
\end{tabular}


The data provided in the table confirm the feasibility of the use of the alternative fuel in the conditions of urban development, as it allows to reduce significantly the bursts of $\mathrm{CO} 2$ in the atmosphere and to reduce the harm, done to the health of the urban population.

Natural sources (solar batteries, hydrogen fuel, the biodiesel, fuel from water vapour, etc.) and also gas motor fuel can be used as such fuel. $3[8]$

The expected data on the use of gas engine vehicles in Russia are presented in the figure

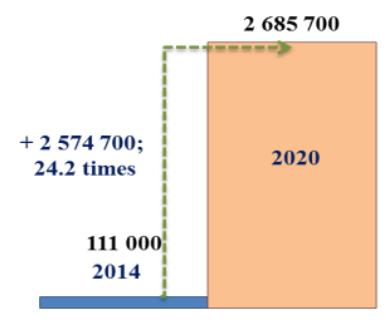

Fig. 3. The forecast of number of vehicles, using gas motor fuel in the Russian Federation

The growth of number of the vehicles, using gas motor fuel by 24 times (up to 2685 700 units) in comparison with the current data of 2014 is predicted by 2020; that will allow to reduce considerably the emissions of greenhouse gases in the atmosphere and ecological expenses in the conditions of urban development.

Considering the ecological expenses it is possible to allocate two essentially different components conditionally:

- the expenses on preventions of pollution (the expenses, connected with implementation of actions for environmental protection, directly);

- the expenses, connected with compensation or mitigation of consequences of pollution, that is the economic damage from the violation of components of the surrounding environment.

Expenses of prevention of the damage, caused by the logistics system to the urban development, represent costs of introduction of low-waste, resource-saving technologies. This type of expenses can act as capital (single) expenditure.

Expenses of elimination (compensation) of consequences of pollution are the result of the impact of the polluted environment on recipients and they are treated as economic damage from environmental pollution. At the level of the separate enterprise the economic damage is presented by loss (short-reception) of profit and additional expenses.

Nowadays ecological taxes and fees for emissions in the atmosphere are not collected from the vehicles in the modern cities of the Russian Federation [2] though such practice is widespread in Luxembourg, Japan, Germany, Romania, and Ireland. In Russia the payment for emissions is carried out only for the motor transport congestion source, for example for official parkings.

It should be noted, that "Transport strategy of the Russian Federation until 2030» include regulations on the introduction of the ecological tax on the cars polluting the environment. Thus the Government of the Russian Federation is trying to stimulate the manufacturing companies to make eco-friendly vehicles, and potential buyers to choose the most eco-friendly cars.

At the same time logistic costs have to include both the economic component, including the expenses appearing during transportation, storage of goods and information support of the processes of merchandising, and ecological expenses. The structure of ecological costs assumes accounting of expenses of two components: the costs of prevention of damage to 
the urban environment and the costs of elimination (compensation) of negative impact by the logistics system on the environment.

Thus, total logistic costs can be defined as the costs of the enterprise for ensuring the movement of material and accompanying streams, expressed in the monetary form, between the primary source and the consumer, for prevention and compensation of negative impact of this movement on the urban environment [19].

The theory of logistics presents the following model of the total logistic cost: [9]

$$
\sum \mathrm{C}=\mathrm{Cp}+\mathrm{Co}+\mathrm{Cs}+\mathrm{Cd}+\mathrm{Ct}+\mathrm{Cl}
$$

where $\mathrm{Cp}$ - the costs connected about acquisition of production;

Co - the costs connected with registration and execution of the order, including transportation and loading-unloading operations;

$\mathrm{Cs}$ - the costs connected with storage of the current and insurance stocks;

$\mathrm{Cd}-$ the costs reflecting losses from deficiency of production;

$\mathrm{Ct}$ - the costs connected with violation of terms of delivery;

$\mathrm{Cl}$ - the latent (hidden) costs.

In case of introduction of technologies of "green" logistics the model of the general logistic expenses will also include the costs of payment of ecological payment. The model of the total logistic costs, taking into account an ecological factor, can be presented in the following form:

$$
\sum \mathrm{C}=\mathrm{Cp}+\mathrm{Co}+\mathrm{Cs}+\mathrm{Cd}+\mathrm{Ct}+\mathrm{Cl}+\mathrm{Cecol}
$$

The main components of the model of total logistic costs (TLC) which will react in case of taking into account the ecological factor is made up the costs of purchase of goods, registration and the organization of the order and also costs of storage of goods. The size of the costs, connected with the deficiency of goods, penalties and also the volume of latent costs, when using technologies of "green" logistics will obviously not change.

The growth of costs of acquisition of production is caused by work with suppliers, whose activity is more eco-friendly. The example is production more ecologically acceptable material or product. Thus the cost of such goods will increase [24].

The growth of the costs, connected with the implementation of the order is caused by the growth of transport expenses, which main reason is the transition of the enterprise to more ecologically acceptable fuel.

Costs of storage will also increase as the share of costs of storage depending on the price of a unit of production increases.

These components can be presented in the following form [4, 9]:

$$
\Sigma \mathrm{C}=\mathrm{A} * \mathrm{Pu}+\frac{A * C_{O}}{S}+\frac{P_{u} * f * S}{2}
$$

where A - the need for production during the considered period;

$\mathrm{Pu}$ - the price of a unit of production;

Co - costs, connected with the organization and implementation of one order;

$\mathrm{S}$ - volume of the set of the order (delivery);

$\mathrm{f}$ - the share of costs of storage depending on the price of a unit of production.

Thus, applying this formula it is possible to calculate the total logistic costs before taking into account of the ecological factor.

For calculation of the total logistic costs it is necessary to determine the optimum volume of the order Sopt. We will use the classical formula of EOQ: [4, 17] 


$$
\mathrm{S}_{\mathrm{opt}}=\sqrt{\frac{2 A * C_{0}}{P_{u} * f}}
$$

Basic data for carrying out the cost assessment of ecological damage from gas emissions in St. Petersburg are presented in Table 2.

Table 2. Basic data for the cost assessment of ecological damage of logistic activity in St. Petersburg in $2017[6,12]$

\begin{tabular}{|l|c|}
\hline \multicolumn{1}{|c|}{ Indicators } & Values \\
\hline Specific damage $(\mathrm{g})$, roubles per equivalent ton of fuel & 48.4 \\
\hline Indicator of relative danger of the exhaust gases $(\sigma)$ & 8 \\
\hline $\begin{array}{l}\text { Dimensionless value, which is responsible for the nature of } \\
\text { dispersion of impurity in the atmosphere }(\mathrm{f})\end{array}$ & 451900 \\
\hline $\begin{array}{l}\text { Mass of the annual emission polluting substances of the } \mathrm{i}_{\text {th }} \\
\text { type }(\mathrm{M}), \text { ton in year }\end{array}$ & 20 \\
\hline $\begin{array}{l}\text { Indicator of relative aggression of pollutant }(\mathrm{A}), \text { equivalent } \\
\text { ton of fuel in a year }\end{array}$ & 1.21 \\
\hline $\begin{array}{l}\text { Indexation of specific damage, taking into account inflation } \\
\left.\text { (It }{ }_{\text {ind }}\right)\end{array}$ & \\
\hline
\end{tabular}

Let us calculate the value of the economic damage (ED):

$\mathrm{EU}=451.9$ thousand ton in a year $* 10 * 1.21 * 48.4$ roubles per equivalent tons of fuel * 20 equivalent tons of fuel in year $=5293$ million roubles.

Thus, the ecological damage, caused by logistic activity in 2017 was 5293 million roubles. This assessment is integrated; however it is sufficient to estimate damages to the society and the level of costs of its compensation for St. Petersburg. According to the calculation, the cost of damage is great, and the total ecological payment is rather small to cover the caused damage to the city. The cost of ecological damage also testifies to the impressive costs for the state of treatment and improvement of the population. It is obvious, that accounting of ecological costs will affect the size of total logistic costs. However, the methodology of account and assessment of these costs is not developed in the current scientific literature. According to some experts [30] the application of the concept of "green" logistics without introduction of expensive low-waste and resource-saving technologies will help to reduce logistic costs of 5-20\%.

During calculation of the EOQ model as the criterion of optimization the minimum of the total costs, including costs of implementation of the order and costs of storage of the stock in the warehouse is accepted.

Further we will consider TLC model components, taking into account an ecological factor. When purchasing more eco-friendly goods, the price of production will raise. When using more eco-friendly type of fuel also its price will change. Growth of costs of fuel will lead to the growth of costs of implementation of the order, etc. Thus, it is possible to conclude, that when accounting the ecological factor total logistic expenses raise because of growth of costs of purchase, implementation of the order and also storage of a stock in a warehouse $[25,30]$.

This factor certainly interferes with the introduction of the concept of "green" logistics by the domestic enterprises. In this situation stimulating impact has to make the public and regional government [23].

In this situation it is unprofitable for the enterprise to get this type of technology, as the total cost of assets will increase and that is adverse to affect the revenue on assets (ROA) of 
the enterprise. This indicator is the best consolidated indicator of functioning of the enterprise. [17, 32]

In case of detection of the changes in the external environment, determined by townplanning factors as well, the algorithm provides the analysis of the total logistic costs on the basis of the TLC model.

Traditional decisions on the change of schemes of the use of transport networks of the city, for example, extend due to the change of the way of transportation of a load (the use of intermodal transportations), application of consolidation of loads, etc. [23, 29]

As a rule, application of these actions will help to lower the total logistic costs and the level of the ecological damage in the conditions of the modern city, however will perhaps cause decrease in such indicators of efficiency of logistics as quality of logistic service, duration of logistic cycles, productivity, return on investment into logistic infrastructure.

For the assessment of level of logistic expenses it is necessary to calculate the ecological damage which is caused by logistic activity. "Temporary technique", given above, and data on the damage, caused by cars, can be used for calculation.

\section{Discussions}

The complexity of determination of the efficiency of introduction of "green" logistics in the conditions of the modern city is caused by the existence of some contradictions between achievement of economic efficiency of logistics and ensuring ecological safety (Table 3).

Table 3. Contradictions among the economic and ecological targets and problems of logistic activity

\begin{tabular}{|l|l|l|}
\hline \multicolumn{1}{|c|}{ Disagreement subject } & \multicolumn{1}{|c|}{ Ensuring of economic efficiency } & \multicolumn{1}{|c|}{$\begin{array}{c}\text { Ensuring ecological safety of the } \\
\text { urban development }\end{array}$} \\
\hline $\begin{array}{l}\text { Costs and distribution } \\
\text { of funds }\end{array}$ & Minimization of costs & $\begin{array}{l}\text { Need of considerable assignment } \\
\text { for the nature protection actions }\end{array}$ \\
\hline $\begin{array}{l}\text { Organization of system } \\
\text { of supply and choice of } \\
\text { suppliers }\end{array}$ & $\begin{array}{l}\text { Optimization of capital } \\
\text { investments and procuring costs }\end{array}$ & $\begin{array}{l}\text { Choice of the suppliers, meeting } \\
\text { ecological requirements }\end{array}$ \\
\hline $\begin{array}{l}\text { Organization and } \\
\text { flexibility of } \\
\text { distribution systems }\end{array}$ & $\begin{array}{l}\text { Ensuring system-wide efficiency } \\
\text { of the distribution systems by the } \\
\text { means of network changes (the } \\
\text { integrated chains of deliveries, } \\
\text { nodal and step structures of } \\
\text { distribution, Internet trade) }\end{array}$ & $\begin{array}{l}\text { Organization of the distribution } \\
\text { systems, consuming less space, } \\
\text { elements of infrastructure, energy } \\
\text { and resources }\end{array}$ \\
\hline $\begin{array}{l}\text { Time, accuracy and } \\
\text { reliability of delivery }\end{array}$ & $\begin{array}{l}\text { Use of large cargo and air } \\
\text { transport, socially significant } \\
\text { components of infrastructure }\end{array}$ & $\begin{array}{l}\text { Development of the optimum } \\
\text { routes and ways of cargo transfer, } \\
\text { which do not create any tension on } \\
\text { roads and optimum from the point } \\
\text { of view of environmental } \\
\text { protection }\end{array}$ \\
\hline Transportation system & $\begin{array}{l}\text { Transportation of large } \\
\text { consignments of goods by } \\
\text { economical means of transport }\end{array}$ & $\begin{array}{l}\text { Expeditious transportation of small } \\
\text { consignment of goods by the } \\
\text { modern means of transport, } \\
\text { consuming less fuel }\end{array}$ \\
\hline
\end{tabular}

Thus, it is possible to conclude, that use of the concept of «green" logistics has some economic and ecological contradictions, and components of logistic and ecological costs will depend on the level of optimization of logistic streams of the enterprise, logistic strategy and also making decisions on the use of some tools and methods of decrease in negative impact on the urban environment. 
The regulation of the negative impact of the enterprise from the state serves as the incentive of introduction of ecological technologies for the companies and so do various methods of financial compensation of expenses of the enterprise at the municipal, regional and state level [27, 28].

Conceptual provisions on the improvement of economic instruments of regulation of the negative impact of logistics systems of the enterprises in the modern city are offered in Table 4. These measures assume the decrease in the negative impact of logistics systems on the urban environment due to the use of more eco-friendly types of fuel, transport, transition to intermodal type of transportations. The implementation of credit policy and introduction of privileges will also stimulate the enterprises to introduce the expensive energy saving and low-waste technologies.

On the one hand, the offered measures, stimulate the enterprises to introduce the concept of "green" logistics, on the other hand, they are the basis for the sustainable development of the modern cities.

Table 4. Offers on the decrease in the negative impact of logistics systems on the environment

\begin{tabular}{|c|c|}
\hline Level & Ways of the increase in environmental friendliness of the urban environment \\
\hline $\begin{array}{c}\text { Federal and } \\
\text { regional } \\
\text { authorities }\end{array}$ & $\begin{array}{l}\text { The use of various norms, standards, restrictions: } \\
\text { - standards of the contents of chemicals in the exhaust gases; } \\
\text { - prohibition restriction for the entrance into some territories in } \\
\text { the specified time for certain means of transport; } \\
\text { - quality standards of fuel. }\end{array}$ \\
\hline & $\begin{array}{l}\text { use } \text { improvement of aerodynamic properties of cargo transport (the } \\
\text { technologies, reducing drag coefficient allows to cut fuel consumption } \\
\text { for } 15-20 \% \text { [20]; } \\
\text { Enterprise }\end{array}$ \\
$\begin{array}{l}\text { - observance of the optimum high-speed mode; } \\
\text { - reduction of stop quantity; }\end{array}$ \\
$\begin{array}{l}\text { - appropriate maintenance of vehicles; } \\
\text { - the use of alternative types of fuel; } \\
\text { - the use of technical means of control of the vehicle location; } \\
\text { - optimization of loading-and-unloading; } \\
\text { - planning of the optimum routes, taking into account traffic jams. }\end{array}$ \\
\hline
\end{tabular}

\section{Conclusions}

As the result of the analysis of state regulation of ecological activity of the enterprises of the modern city and the assessment of introduction of the concept of "green" logistics by the domestic enterprises the author conclude, that introduction of this concept for the enterprises is economically unattractive. For estimation of the main logistic costs, using the concept of "green" logistics it is necessary to use of the model of the total logistic costs, as they are one of the most important indicators of efficiency of logistic activity. It is also important to decide, what components of the model will be modified, when using this concept.

Application of the offered package of measures for the support of the company at the municipal and regional levels will allow the state to begin the policy of intrenalization of externalities; that will lead to considerable reduction of expenses of the budget by compensation of the ecological damage, caused by logistic activity in the modern city. On the other hand, the level of negative impact on the urban environment will decrease considerably.

The long-term aspect of actions will allow to formulate theoretically some reasonable and almost effective mechanisms of management of external expenses in the conditions of 
the modern city. Such decisions include measures for prevention of negative impact, development of measures for ecological safety of sustainable development of built-up territories.

The short-term aspect of actions is directed to work for elimination of inaccuracies, because of which introduction and collection of ecological payment for negative impact on the urban environment makes no sense. The short-term aspect of actions will allow solving the most acute environmental problems. The main feature of these actions is harmonization and adaptation of economic instruments of decrease in influence of the enterprises on the environment.

Formation of the principles of "green" logistics in Russia only begins to develop, positive tendencies to formation of this direction of activity of the logistic companies in territories of the modern cities are observed.

Methods and tools of "green" logistics both in scales of the state, and at the level of the certain city will allow to reduce the general cumulative emissions of greenhouse gases, to order activity of the logistic companies and to provide sustainable development at all the levels of interaction of society with the environment and the necessary level of ecological safety of modern building of the cities of our country.

\section{References}

1. Temporal technique of determination of the prevented ecological damage (Moscow, State. committee of the Russian Federation on environmental protection, 1999)

2. Resolution of the Government of the Russian Federation "On the calculation and collection of payment for the negative impact on the environment" 03.03.2017 No. 255

3. The federal law of the Russian Federation "On environmental protection" 10.01.2002 No. 7-FZ

4. D. Bowersoks, D. Klos, Logistics: the integrated circuit of deliveries. (Moscow, CJSC Olimp-Business, 2001)

5. S.N. Bobyliov, V.N. Sidorenko, Yu.V. Safonov, S.L. Avaliani Macroeconomic assessment of costs from environmental pollution for the health of the population of Russia (Ying t of the World Bank, Fund of protection of the nature, Moscow, 2002)

6. I.A. Grigoriev, Report on the ecological situation in St. Petersburg in 2016 (SPb.: LLC Sezam-print, 2017)

7. M.A. Zhuravskaya, "Green" logistics - the strategy of success in development of the modern transport [Digital resource] URL Access mode: https://www.researchgate.net/publication/275830871_Green_logistics_-_ a_strategy_for_success_in_the_development_of_modern_transport_industry

8. A.G. Ishkov, K.V. Romanov, R.V. Teterevlev, Ecological year-book, 3-13 (2016)

9. V.S. Lukinsky, Materials of the International scientific and practical seminar "GreenLogistics: The future of logistics", 45-48 (2011)

10. N.O. Margate, U.Z. Bilonizhka, Scientific log of SUMDU. Marketing series and management of innovations, 279-286 (2014)

11. O.A. Mishchenko, L.P. Mayorova, TOGA Bulletin, 2 (9), 167-179 (2008)

12. Federal State Statistics Service official site [Digital resource] URL Access mode: http://www.gks.ru/

13. V. P. Postnikov, N.M. Levda, PNIPU Bulletin. Social-and-economic sciences, 21, 8189 (2013)

14. Action program. The agenda for the 21 st century and other documents of a conference in Rio de Janeiro in popular presentation. (Geneva: Center for our general future)

15. V.F. Protasov, A.V. Molchanov, Ecology, health and environmental management in Russia (Moscow, Finance and statistics, 1995) 
16. E.V. Ryumina, Economy of environmental management, 4, 39-46 (2008)

17. J.R. Stock, D.M. Lambert, Strategic control of logistics. In Russian (Moscow, INFRAM, 2005)

18. E.Yu. Tsebekova, E.Yu. Pykhova, Green logistics: theoretical aspects (Voronezh, Panorama Publishing house, Voronezh State University, 2015)

19. Yu.V. Chortok, Ecologo-economic efficiency of different types of transport in the conditions of a logistics system (VTD "University Book", 2009)

20. V. Chekhuta Turbulence now not a problem, [Digital resource] Access Mode- The free access of the Internet:

http://www.os1.ru/article/business/2008_03_A_2008_11_0519_39_04/

21. Digital resource, Access Mode:

http://www.unece.org/fileadmin/DAM/trans/doc/2016/wp24/ECE-TRANS-WP.242016-04r.pdf

22. Factors influencing health of the person [Digital resource] Access Mode: http://www.moluch.ru/ archive/40/4754/

23. Haw-Jan Wu, International Journal of Physical Distribution \& Logistics Management, 25 (2), 20-38 (1995)

24. R. Handfield, S.V. Walton, R. Sroufe, S.A. European Journal of Operational Research, 141-1, 70-87 (2002)

25. International Conference on Improving Fuel Economy and Reduction of Emissions from Road Transport in Russia Held [Digital Resource] Access Mode: http://www.slideshare.net/fullscreen/undprussia/the-global-fuel-economy-initiativegfei...]

26. Li Yanbo, Xiamen: Xiamen University of Technology, 4, 290 -298 (2008)

27. Nakul Sathaye, The Environmental Impact of Logistics Systems and Options for Mitigation (UC Center for Future Urban Transport, working paper UCB - ITS-VWP. 2006)

28. P.R. Murphy. [Digital Resource]: Green logistics: Comparative views of environmental progressives, moderates, and conservatives; Access Mode http://findarticles.com/p/articles/mi_qa3705/is_199601/ai_n8748499/print.

29. Ds. Rogers, Journal of Business Logistics, 22 (2), 129-145 (2001)

30. J.-P. Rodrigue, S. Brian, C. Claude, Handbook of Logistics and Supply-Chain Management (2001)

31. Samir K. Srivastava, International Journal of Management Reviews, 1, 53-80 (2007)

32. T. Tereshkina, S. Tereshchenko, T. Bezrukova, E. Drevaleva, O. Pecherskaya, Improvement of Methods of Analysis of Effectiveness of Stock Management at Industrial Enterprises» Integration and Clustering for Sustainable Economic Growth (Springer International Publishing AG, 2017)

33. Yingying Xia, BoWang, Green logistics in logistics industry in Finland (Finland: Lahti University of Applied Sciences, 2013) 